IPP into DMAPP in higher plants, as in yeast and mammalian tissuc.

The first conclusion differs from that obtained in previous investigations of monoterpene biosynthesis in leaf and stem tissue, excluding the methyleyclopentanoid monoterpenes. The existence of a metabolic pool of DMAPP, a non-MVA source for this compound, or the operation of appropriate compartmentation effects can explain the previous labelling results: presumably such factors do not operate in petals. Thus leaf and stem tissue contain discrete oil glands not seen in petal tissue.

We thank Unilever (London) Ltd for a studentship to G. N. J. Le P.

$$
\text { M. J. O. FraNCIS* }
$$

Unilever Research Laboratory,

Colworth House,

Sharnbrook, Bedfordshire.

D. V. Banthorpe

G. N. J. Le Patourel

Department of Chemistry,

University College London,

20 Gordon Street,

London WC1.

Received Mareh 18, 1970.

* Present addresss: Department of Orthopacdic Surgery, Nuffield Orthopaedic Centre, Headington, Oxford ox 3 7LT.

${ }^{1}$ Loomis, W. J)., in Terpenoids in Plants (edit. by Pridham, J. B.), 59 (Academic Press, New York, 1967).

${ }^{2}$ Banthorpe, D. V., and Turnbull, K. W., Chem. Commun., 177 (1966).

${ }^{3}$ Banthorpe, I. V., and Baxendale, I., Chem. Commun., 1553 (1968).

4 Charlwood, B. Y., thesis, Cniv, London (1970).

${ }^{5}$ Biollaz, M., and Arigoni, 1., Chem. Commun., 633 (1969).

${ }^{\circ}$ Godin, P. J., Inglis, H. S., Snarey, M., and 'Thain, E. M., J. Chem. Soc., 5878 (1963).

${ }^{2}$ Francis, M. J. O., and Allcock, C., Biochem. J.,113, 38P (1969).

${ }^{8}$ Francis, M. J. O., and Allcock, C., I'hytochemistry, 8, 1339 (1969).

${ }^{9}$ Francis, M. J. O., and $0^{\prime}$ Connell, M., Phytochemistry, 8, 1705 (1969)

${ }^{10}$ Cornforth, J. W., and Popjak, G., Biochem. J., 58, 404 (1954).

"Battersby, A. R., and Taylor, W. I., Cyclopentunoid Monoterpene Derivatives (Marcel Dekker New York, 1969).

12 Cornforth, J. W., Quart. Rev. Chem. Soc., 23, 125 (1969).

\section{Short Term Test for Evaluating Potential Carcinogenic Activity of Tobacco Condensates}

Mouse skin has been used for many years as a convenient tissue for the assay of tumorigenic propertics of tobacco conderisates. This testing is prolonged and expensive, and the value of the results obtained is controversial; it is therefore desirable to find a way of shortening the experimental procedure. Scbaccous glands provide a convenient route of entry for substances painted on to the skin, and in particular for the lipid soluble carcinogenic hydrocarbons found in tobaceo condensates, which can, in fact, be labelled and located in these glands. Polycyclic hydrocarbons in particular have been used to dernonstrate the possibility of using destruction of sebaceous glands to indicate potential carcinogenic activity, and Bock and Mund ${ }^{1,2}$ showed that if compounds with a benzanthracene structure are used the degree of destruction is related to tumorigenic activity. Unfortunately, some carcinogenic substances in which the benzanthracene structure is absent (for example, 7,9-dimethylbenz $(c)$ acridine) do not destroy the scbaccous glands; but this does not apply to tobaceo condensates ${ }^{3}$.

The development of image analysers ${ }^{4,5}$ which can rapidly calculate area size of oddly shaped structures, and of reliable enzyme histological methods, have solved the main problems of analysing gland suppression data. The new technique involves the demonstration of non-specific esterase enzymes in the skin of mice painted with tobacco condensates or other carcinogenic hydrocarbons, and the evaluation of areas covered by this enzyme. Non-specific esterase demonstrated by the indoxyl-acetate method of Holt $^{6}$ seems to be confined to the sebaceous glands and a few nerve fibres.

Groups of 12 SPF mice (CFLP) each 50 days old to avoid the complication of cyclic hair growth changes were painted on three consecutive days with various doses of three different tobacco condensates and various other potentially carcinogenic substances. Four days after application of the final dose all the mice were killed and a piece of skin from the painted area was frozen in hexane pro-cooled to $-75^{\circ} \mathrm{C}$. Twelve $40 \mu \mathrm{m}$ cryostat sections were cut transversely from each piece of skin, fixed in formol-calcium-gum-sucrose and non-specific esterase enzyme demonstrated as described. The total area of reaction product contained in 3,000 fields (each measuring $68,000 \mu^{2}$ ) from each group of animals was measured with a 'Quantimet B' image analyser. The reading took about $2 \mathrm{~h}$ per group, all the groups being read by an operator with no prior knowledge of which compound had been painted. Results (Table 1) show a direct relationship between area of enzyme activity and known carcinogenic activity of the compound. All the tobacco condensates were ranked in dose and tumorigenic order as previously established by long term tumour production methods.

Table 1. RELATIONSHIP OF AREA OF KNZYME ACTIVITY TO KNOWN CARCINOGENIC ACTIVITY

\begin{tabular}{|c|c|c|c|c|}
\hline \multicolumn{2}{|l|}{ Compound } & \multicolumn{2}{|c|}{$\begin{array}{c}\text { Area }\left(\mu \mathrm{m}^{2}\right) \text { of estcrase } \\
\text { Dose } \quad \begin{array}{c}\text { activity (mean of } \\
3,000 \text { flelds) }\end{array}\end{array}$} & $\begin{array}{l}\text { Tumour yield from } \\
\text { long term tests } \\
\text { (80 wecks*) per cent }\end{array}$ \\
\hline Tobaco condensate & e A & $36 \mathrm{mg}$ & 156 & 38 \\
\hline & $A$ & $60 \mathrm{mg}$ & 64 & 48 \\
\hline & $A$ & $100 \mathrm{mg}$ & 36 & 77 \\
\hline & 13 & $36 \mathrm{mg}$ & 450 & 12 \\
\hline & $\mathrm{B}$ & $60 \mathrm{mg}$ & 348 & 32 \\
\hline & 13 & $100 \mathrm{mg}$ & 63 & 33 \\
\hline & C & $36 \mathrm{mg}$ & 522 & 8 \\
\hline & $\mathrm{C}$ & $60 \mathrm{mg}$ & 339 & 25 \\
\hline & C & $100 \mathrm{mg}$ & 99 & 27 \\
\hline DMBA & & $250 \mu \mathrm{g}$ & 51 & - \\
\hline Trethane & & $25 \mathrm{mg}$ & 1,392 & - \\
\hline $\begin{array}{l}\text { Acetone (solvent) } \\
\text { trol (1) } \\
\text { Acetone (solvent) }\end{array}$ & con- & $0.33 \mathrm{ml}$. & 2,796 & - \\
\hline $\begin{array}{l}\text { Acctone (solvent) } \\
\text { trol (2) }\end{array}$ & con- & $0.33 \mathrm{ml}$. & 2,549 & - \\
\hline Croton oil & & 0.1 per cent & 2,067 & \\
\hline
\end{tabular}

This test is not entirely spocific for carcinogenic activity and probably relates more to the toxicity of the painted substance to the sebaceous gland cells. It is, however, remarkable that within the range of substances tested this toxicity is directly related to carcinogenicity; and it scems therefore to be a useful rapid screen for potential carcinogenic hazards in tobacco condensates.

\section{Peter Healey \\ Lionel E. Mawdesley-Thomas \\ DaVID H. BARRY}

Department of Pathology,

Huntingdon Research Centre,

Huntingdon.

Received May 27, 1970.

${ }^{1}$ Bock, F., and Mund, R., J. Invest. Derm., 26, 479 (1956).

${ }^{2}$ Bock, F., and Mund, R., Cancer Res., 18, 887 (1958).

${ }^{3}$ Healey, P., Mawdesley-Thomas, L. E., and Barry, D. H., Proc. Tenth Intern. Cancer Cong. (1970) (in the press).

4 Mawdesley-Thomas, L. E., and Healey, P., New Sci., February 6, 286 (1969).

s Mawdesley-'Thomas, L. E., and Healey, P., Science, 163, 1200 (1969).

${ }^{6}$ Holt, S. J., General Cytochemical Methods (edit. by Danielli, J. F.), 1, 375 (Ácademic Press, New York, 1958). 